5 Larose P, Meloche S, Du Souich P, De Léan A, Ong H. Radio-immunoassay of atrial natriuretic factor: human plasma levels. Biochem Biophys Res Commun 1985;130:553-8.

6 Shenker Y, Sider RS, Ostafin EA, Grekin RJ. Plasma levels of immunoreactive atrial natriuretic factor in healthy subjects and in patients with edema. $f$ Clin Invest 1985;76:1684-7.

7 Yamagi T, Ishiboshi $M$, Takaku F. Atrial natriuretic factor in human blood. $\mathcal{f}$ Clin Invest 1985;76:1705-9.

8 Ogawa $\mathrm{K}$, Ito $\mathrm{T}$, Hoshimoto $\mathrm{H}$, et al. Plasma atrial natriuretic factor in congestive heart failure. Lancet 1986; i:106.

9 Rascher W, Tulassay T, Lang RE. Atrial natriuretic peptide in plasma of volume-overloaded children with chronic renal failure. Lancet 1985;i:303-5.

10 Schiffrin EL, Gutkowska J, Kuchel O, Cantin M, Genest J. Plasma concentration of atrial natriuretic factor in patient with paroxysmal atrial tachycardia. N Engl f Med 1985;312:1196.

11 Cusson JR, Gutkowska J, Rey E, Michon N, Boucher M, Larochelle P. Plasma concentration of atrial natriuretic factor in normal pregnancy. $N$ Engl f Med 1985;313:1231.

12 Richards AM, Nicholls MG, Ikran H, Webster MWI, Yandle TG, Espiner EA. Renal haemodynamics and hormonal effects of human alpha atrial natriuretic peptide in healthy volunteers. Lancet 1985; ; 545 -9.

13 Richards AM, Nicholls MG, Espiner EA, et al. Effect of alpha human atrial natriuretic peptide in essential hypertension. Hypertension 1985;7:812-7.

14 Bussien JP, Biollaz J, Waeber B, et al. Dose dependent effect of atrial natriuretic peptides on blood pressure, heart rate and skin blood flow of normal volunteers. I Cardiovasc Pharmacol 1986;8:216-20.

15 Arendt RM, Stangl E, Zahringer J, Liebesch DC, Hertz A. Demonstration and characterization of human atrial natriuretic factor in human plasma. FEBS Lett 1985;189:57-61.

16 Sugawara A, Nakao K, Sakamoto $M$, et al. Plasma concentration of atrial natriuretic polypeptide in essential hypertension. Lancet 1985; 1 i: 1426-7.

17 Sagnella GA, Markanda ND, Shose AC, MacGregor GA. Raised circulating levels of atrial natriuretic peptides in essential hypertension. Lancet 1985;i:179-81.

18 Gutkowska J, Boucher R, Genest J. Dosage radioimmunologique de l'activité rénine plasmatique. Union Med Can 1977; 106:446-50.

19 Underwood B, Williams GH. The simultaneous measurement of aldosterone, cortisol and cortircsterone in human peripheral plasma by displacement analysis. $\mathrm{f} \mathrm{Lab} \mathrm{Clin} \mathrm{Med}$ 1972;79:848-62.

20 Garcia R, Thibault G, Gutkowska J, et al. Chronic infusion of low doses of atrial natriuretic factor (ANF Arg 101-Tyr 126) reduces blood pressure in conscious SHR without apparent changes in (ANF Arg 101-Tyr 126) reduces blood pressure in conscious

21 Garcia R, Thibault G, Gutkowska J, Hamet P, Cantin M, Genest J. Effect of chronic infusion of synthetic atrial natriuretic factor (ANF 8-33) in conscious two-kidney, one clip hypertensive rats. Proc Soc Exp Biol Med 1985;178:155-9.

22 Garcia R, Gutkowska J, Genest J, Cantin M, Thibault G. Reduction of blood pressure and $\underline{\underline{W}}$ increased diuresis and natriuresis during chronic infusion of atrial natriuretic factor (ANF Arg 101-Tyr 126) in conscious one kidney, one clip hypertensive rats. Proc Soc Exp Biol Med 1985;179:539-45.

23 De Léan A, Vinay P, Cantin M. Distribution of atrial natriuretic factor receptors in dog kidney 2 fraction. FEBS Lett 1985;193:239-42.

24 Chartier L, Schiffrin EL, Thibault G, Garcia R. Atrial natriuretic factor inhibits the stimulation of $\widehat{\widehat{\Omega}}$ aldosterone secretion by angiotensin II, ACTH and potassium in vitro and angiotensin II-induced steroidogenesis in vivo. Endocrinology 1984;115:2026-8. 25 Schiffrin EL, Chartier $L$, Thibault G, St-Louis J, Cantin M, Genest J. Vascular and adrenal $\underset{\mathbb{D}}{\text { receptors for atrial natriuretic factor in the rat. Circ Res 1985;56:801-7. }}$

26 Hamet P, Tremblay J, Pang SC, et al. Effect of native and synthetic atrial natriuretic factor on TI cyclic GMP. Biochem Biophys Res Commun 1984;123:515-27.

27 Hollister AS, Tanaka I, Iamada T, et al. Sodium loading and posture modulates human atrial $\cdots$ natriuretic factor plasma levels. Hypertension 1986;6(suppl II): 106-11.

28 Padfield PL, Beiners DG, Brown JJ, et al. Is low renin hypertension a stage in the development of essential hypertension or a diagnostic entity? Lancet 1975; i:548-54.

29 Villarenal D, Freeman RH, Davis JO, Verburg KM, Van RC. Renal mechanisms for suppression of renin secretion by atrial natriuretic factor. Hypertension 1986;8(suppl II):28-35.

30 Anderson JV, Christofides ND, Bloom SR. Plasma release of atrial natriuretic peptide in response $\frac{\omega}{\sigma}$ to blood volume expansion. $\mathcal{f}$ Endocrinol 1986;109:9-13.

31 Shenker Y, Seder RS, Ostafin EA, Greken RJ. Plasma levels of immunoreactive atrial natriuretic factor in healthy subjects and in patients with edema. $\mathcal{f}$ Clin Invest 1985;76:1684-7.

32 Tanaka $\mathrm{H}$, Shindo $M$, Gutkowska J, et al. Effect of acute exercise on plasma immunoreactiveatrial natriuretic factor. $L$ ife Sci 1986;39:1685-93.

$33 \mathrm{Kouz}$ S, Bourassa MG, Laurier J, et al. Plasma concentration of immunoreactive atrial natriuretic factor (IR-ANF) in patients with coronary artery disease. fournal of the American College of $\overrightarrow{\vec{v}}$ Cardiology 1986;7(suppl A):2.

34 London GM, Safar ME, Safar AL, Simon ACH. Blood pressure in the "low-pressure system" and cardiac performance in essential hypertension. Fournal of Hypertension 1985;3:337-42.

35 Olivari MT, Fiorentini C, Polese A, Guazzi MD. Pulmonary hemodynamics and right ventricular function in hypertension. Circulation 1978;57:1185-6.

(Accepted 17 February 1987)

\title{
Influence of salt on glycaemic response to carbohydrate loading
}

\author{
R O B GANS, R J HEINE, A J M DONKER, E A VAN DER VEEN
}

\begin{abstract}
The effect of dietary salt on glycaemic responses to different test meals was investigated. Eight healthy male volunteers ate four test meals on consecutive mornings and in random order; the meals were $50 \mathrm{~g}$ carbohydrate taken as a $20 \%$ glucose solution or as boiled macaroni with and without supplementation with $6 \mathrm{~g}$ salt. In contrast with other reports, no significant differences in peak plasma glucose concentrations or areas under the plasma glucose curves could be established.
\end{abstract}

These findings do not support a beneficial effect of salt restriction on glycaemic control in diabetes.

\section{Introduction}

The glycaemic response to standard test meals of various foods varies considerably in both normal volunteers and diabetics. ${ }^{12}$ Thorburn et al recently reported that adding salt to two common starchy foods resulted in an increase of the postprandial plasma glucose and insulin responses. ${ }^{3}$ A possible effect of dietary salt on the digestion of starch or absorption of glucose was postulated. This observation was even more interesting in the light of the observed

Department of Medicine, Free University Hospital, 1117 De Boelelaan, 1081 HV Amsterdam, The Netherlands

R O B GANS, MD, physician

$R$ J HEINE, MD, physician

A J M DONKER, MD, physician

E A VAN DER VEEN, MD, physician

Correspondence to: Dr Gans. association between plasma insulin concentrations and blood pressure. Both Berglund $e t$ al and Lucas $e t$ al found higher insulin concentrations in obese hypertensive patients than in normotensive subjects with the same body mass index ${ }^{45}$ Also in non-diabetic normotensive subjects significant associations of systolic and diastolic blood pressure with insulin concentrations have been observed even after allowing for adiposity. ${ }^{6}$ The possible influence of salt on glucose and insulin responses might therefore be implicated in the effect of dietary salt restriction on blood pressure in essential hypertension.

We have studied the plasma glucose response to a moderate $\delta$ amount of salt added to two foods containing $50 \mathrm{~g}$ carbohydratenamely, a readily absorbed glucose solution and boiled macaroni.

\section{Subjects and methods}

Eight healthy normotensive volunteers with a normal body mass index $\tilde{N}$ took a test meal on four consecutive mornings after an overnight fast. Meals $\underset{\omega}{\mathrm{N}}$ were allocated at random according to a Latin square model and comprised $O$ $50 \mathrm{~g}$ carbohydrate as either $71 \mathrm{~g}$ macaroni boiled for 10 minutes (intrinsic salt 0 content $3.6 \mathrm{mg}$ ) or $250 \mathrm{ml} 20 \%$ glucose with and without the addition of $6 \mathrm{~g}$ sodium chloride. The salt supplement was the only additive allowed. Zero $\&$ time was taken as the time that eating started, and the meal had to be finished in 10 minutes.

Blood samples were drawn from an indwelling antecubital venous cannula

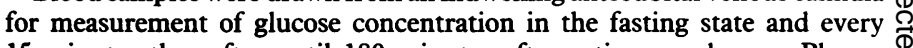
15 minutes thereafter until 180 minutes after eating was begun. Plasma $\triangle$ glucose concentrations were measured by a glucose oxidase method (Yellow Springs glucose analyser, Ohio, USA).

Results are expressed as medians and ranges. Incremental areas under the $\delta$ three hour glucose curves above fasting values were calculated. The Wilcoxon test for paired observations was used for assessing differences $\bar{Q}$ between salted and unsalted meals. The $95 \%$ confidence intervals for the 
BRITISH MEDICAL JOURNAL VOLUME $294 \quad 16$ MAY 1987

eight subjects were calculated as the mean of differences $\pm 2 \cdot 36 \times$ standard error.

\section{Results}

All subjects had normal fasting plasma glucose concentrations (table I). Peak plasma glucose concentrations after the glucose solutions whether supplemented or not with salt were higher than those after the macaroni meals ( $p<0.05$ in both cases). No significant effect on plasma glucose responses was observed after adding salt to the two test meals (table I). Similarly, no differences in the areas under the plasma glucose curves were discernible (table II).

\section{Discussion}

In contrast with Thorburn et $a l,{ }^{3}$ we found no significant difference in glycaemic responses to test meals with and without added salt. The median peak plasma glucose values were almost identical for each test meal with and without the addition of salt. Though there was a trend towards an increase in the glucose absorption rate after the glucose solution with added salt, this did not reach significance owing to the considerable variability in glucose responses. On the other hand, the opposite trend was seen after the macaroni meal, suggesting that adding salt to a carbohydrate meal is unlikely to have a substantial influence on the glycaemic response. As the rate of ingestion of the carbohydrate load was standardised and no significant differences were found in the glycaemic responses to salted and unsalted test meals at the various

TABLE I-Fasting and peak plasma glucose concentrations after test meals in the eight subjects

\begin{tabular}{|c|c|c|c|}
\hline & $\begin{array}{c}\text { Median (range) } \\
\text { fasting plasma } \\
\text { glucose } \\
(\mathrm{mmol} / \mathrm{l})\end{array}$ & $\begin{array}{c}\text { Median (range) } \\
\text { peak plasma } \\
\text { glucose } \\
(\mathrm{mmol} / \mathrm{l})\end{array}$ & $\begin{array}{c}\text { p Value; } \\
95 \% \text { confidence } \\
\text { interval }\end{array}$ \\
\hline $\begin{array}{l}\text { Glucose solution } \\
\text { Glucose solution with salt }\end{array}$ & $\begin{array}{l}4 \cdot 6(4 \cdot 1-4 \cdot 9) \\
4 \cdot 6(4 \cdot 1-4 \cdot 9)\end{array}$ & $\left.\begin{array}{l}7 \cdot 8(5 \cdot 7-8 \cdot 5) \\
7 \cdot 6(6 \cdot 3-9 \cdot 0)\end{array}\right\}$ & 0.401 (NS); -0.53 to 1.03 \\
\hline $\begin{array}{l}\text { Macaroni } \\
\text { Macaroni with salt }\end{array}$ & $\begin{array}{l}4 \cdot 6(4 \cdot 2-5 \cdot 0) \\
4 \cdot 6(4 \cdot 5-4 \cdot 9)\end{array}$ & $\left.\begin{array}{l}6 \cdot 1(5 \cdot 6-7 \cdot 0) \\
6 \cdot 5(4 \cdot 6-7 \cdot 5)\end{array}\right\}$ & 0.726 (NS); -0.84 to 0.69 \\
\hline
\end{tabular}

TABLE II-Areas under plasma glucose curves before and after adding salt to the two test meals

\begin{tabular}{|c|c|c|}
\hline & $\begin{array}{c}\text { Median (range) } \\
\text { area under plasma glucose curve } \\
\text { (mmol min/l) }\end{array}$ & $\begin{array}{l}\text { p Value; } 95 \% \text { confidence } \\
\text { interval }\end{array}$ \\
\hline $\begin{array}{l}\text { Glucose solution } \\
\text { Glucose solution with salt }\end{array}$ & $\left.\begin{array}{r}57 \cdot 8(-63.00 \text { to } 220 \cdot 50) \\
103 \cdot 5(-163 \cdot 00 \text { to } 223 \cdot 50)\end{array}\right\}$ & $0.484(\mathrm{NS}) ;-49.05$ to 101.71 \\
\hline $\begin{array}{l}\text { Macaroni } \\
\text { Macaroni with salt }\end{array}$ & $\left.\begin{array}{l}93.4(-12.00 \text { to } 151.50) \\
60.5(-88.50 \text { to } 154.50)\end{array}\right\}$ & $0.263(\mathrm{NS}) ;-69.46$ to 25.46 \\
\hline
\end{tabular}

time intervals we did not think it necessary to assess plasma insulin concentrations. ${ }^{78}$ In these healthy volunteers no differences were expected, as neither insulin sensitivity nor $\beta$ cell function was influenced during these acute carbohydrate loading experiments. As expected, we confirmed the lower peak plasma glucose concentrations after the macaroni meal as compared with glucose.

This short term study does not support a beneficial effect of salt restriction on glycaemic control in diabetes. Nevertheless, the reported relation between insulin concentrations and blood pressure warrants further study.

\section{References}

1 Jenkins DJA, Wolever TMS, Taylor RH, et al. Glycemic index of foods: a physiological basis for carbohydrate exchange. Am 7 Clin Nutr 1981;34:362-6.

2 Ionescu-Tirgoviste C, Popa E, Sintu E, Mihalache N, Cheta D, Mincu I. Blood glucose and plasma insulin responses to various carbohydrates in type 2 (non-insulin-dependent) diabetes. Diabetologia 1983;24:80-4.

3 Thorburn AW, Brand JC, Truswell AS. Salt and the glycaemic response. Br Med $\mathrm{J}$ 1986;292:1697-9.

4 Berglund G, Larson B, Anderson O, et al. Body composition and glucose metabolism in hypertensive middle-aged males. Acta Med Scand 1976;200:163-9.

5 Lucas CP, Estigarriba JA, Darga LL, Reaven GM. Insulin and blood pressure in obesity. Hypertension 1985;7:702-6.

6 Fournier AM, Gadia MT, Kubrusly DB, Skyler JS, Sosenko JM. Blood pressure, insulin and glycaemia in nondiabetic subjects. $A m \mathcal{J}$ Med 1986;80:861-4.

7 Crapo $P$, Insel J, Sperling M, Kolterman DG. Comparison of serum glucose, insulin and glucagon responses to different types of complex carbohydrate in non insulin-dependent diabetic patients. responses to different types of co

8 Heine RJ, Hanning I, Morgan L, Alberti KGMM. The oral glucose tolerance test (OGTT): effect of rate of ingestion of carbohydrate and different carbohydrate preparations. Diabetes Care 1983;6:441-5.

(Accepted 3 February 1987)

\title{
Delayed cerebellar ataxia: a new complication of falciparum malaria?
}

\author{
NIMAL SENANAYAKE
}

\begin{abstract}
Twelve cases of an unusual phenomenon of ataxia were investigated in otherwise well, conscious patients recovering from a febrile attack of presumed falciparum malaria. The ataxia occurred as the fever was subsiding, usually after an afebrile period of two to four days. The delay between onset of fever and the ataxia was three to four weeks. Peripheral blood of all the patients contained gametocytes of Plasmodium falciparum, and
\end{abstract}

\footnotetext{
Department of Medicine, Faculty of Medicine, University of Peradeniya, Peradeniya, Sri Lanka

NIMAL SENANAYAKE, MD, MRCP, associate professor of medicine
}

in some cases ring stages. The ataxia was most noticeable in the legs and the clinical picture suggested selective impairment of the cerebellar system. Signs of improvement appeared in a few weeks but complete recovery took one to four months.

The most likely pathogenic mechanism of the ataxia in these cases was an immune reaction triggered by the malaria parasite and affecting the cerebellum or its connections, or both.

\section{Introduction}

Neurological manifestations of falciparum malaria range from coma ${ }^{1}$ to muscular paralysis. ${ }^{2}$ This paper draws attention to a unique ataxic syndrome seen recently in Sri Lanka, which may prove to be a new complication of the disease. The outstanding feature was 